\title{
Other Action Taken
}

National Cancer Institute

\section{Source}

National Cancer Institute. Other Action Taken. NCI Thesaurus. Code C82509.

An indication or description that an activity has occurred. 